\title{
Characterization of Shigella spp. by antimicrobial resistance and PCR detection of ipa genes in an infantile population from Porto Velho (Western Amazon region), Brazil
}

\author{
Tatiane Silva, Paulo Afonso Nogueira', Gleiciene Félix Magalhães, Andréa Fagundes Grava, \\ Luiz Hildebrando Pereira da Silva, Patrícia Puccinelli Orlandi/ ${ }^{1+}$ \\ Centro de Pesquisa em Medicina Tropical, Porto Velho, RO, Brasil ${ }^{1}$ Centro de Pesquisa Leônidas e Maria Deane-Fiocruz, \\ R. St. Teresina 476, 69057-070, Manaus, AM, Brasil
}

The incidence of Shigella spp. was assessed in 877 infants from the public hospital in Rondônia (Western Amazon region, Brazil) where Shigella represents the fourth cause of diarrhea. Twenty-five isolates were identified: 18 were Shigella flexneri, three Shigella sonnei, three Shigella boydii and one Shigella dysenteriae. With the exception of S. dysenteriae, all Shigella spp. isolated from children with diarrhea acquired multiple antibiotic resistances. PCR detection of ipa virulence genes and invasion assays of bloody diarrhea and fever (colitis) were compared among 25 patients testing positive for Shigella. The ipaH and ipaBCD genes were detected in almost all isolates and, unsurprisingly, all Shigella isolates associated with colitis were able to invade HeLa cells. This work alerts for multiple antibiotic resistant Shigella in the region and characterizes presence of ipa virulence genes and invasion phenotypesin dysenteric shigellosis.

Key words: Shigella spp. - Brazil - multiple antibiotic resistance - diarrhea - ipa genes

Shigellosis continues to be a major health problem worldwide, occurring predominantly in children younger than five years of age in developing countries. Thus far, the only available information about diarrhea in Rondônia is from previous studies of enteropathogens associated with diarrhea in an infantile population from a district of Porto Velho, where rotavirus appeared as the major etiological agent (Orlandi et al. 2001, 2006).

This study was conducted over a period of 24 months at the Cosme Damião Public Infant Hospital in Porto Velho, Rondônia (Western Amazon region, Brazil) to assess the incidence of enteropathogens in infantile diarrhea. The population was composed mainly of poor inhabitants living in unsanitary conditions. A group of children with nonenteric pathologies was used as a control and PCR detection of ipa virulence genes as well as epithelial invasion assays assessed the presence of wild Shigella spp. This study was approved by the local ethics committee (Center of Tropical Medicine Ethical Committee, Porto Velho, $\mathrm{n}^{\mathrm{o}} 463$ ).

Stool specimens were collected between March 2000-March 2002 using natural or glycerin-induced swabs of 470 children between $0-60$ months of age presenting diarrhea. In addition, 407 children of the same age group with nonenteric pathologies were examined. Dysentery or hemorrhagic colitis was confirmed by the appearance of fever or bloody diarrhea traces in the stool (Feca Cult, One Step Test, INLAB Diagnostica). Shigella spp. in stool samples (cultured in Cary-Blair

Financial support: $\mathrm{CNPq}$

+Corresponding author:patricia_orlandi@amazonia.fiocruz.br

Received 27 November 2007

Accepted 8 September 2008 medium, MacConkey, XLD and Salmonella-Shigella agar) was identified using the 20E System Analytical Profile Index (API-Bio-Merieux). Determination of Shigella serotypes was performed by slide agglutination assays on commercial antisera (Bio-Merrieux). Among the Shigella flexneri isolates, 16 were serotype $2 \mathrm{a}$ and two were serotype 3a. All Shigella boydii were serotype 4 and Shigella disenteriae was serotype 1. Shigella sonnei serotyping was not determined.

Antimicrobial sensitivity tests were conducted according to Mates et al. (2000), using commercially available Mueller-Hinton agar disks (Difco) containing antibiotics against enterobacteria (ampicillin, penicillin, amoxicillin-clavulanic acid, azitromicin; nalidixic acid, ciprofloxacin, norfloxacin; cefitriaxone; chloranphenicol and trimethoprim-sulfamethoxazole). To control for sensitivity, we used Escherichia coli ATCC25922 strain and azitromicin sensitivity assay the Staphylococcus aureus ATCC25923 strain.

PCR detection of ipaB, ipaC, ipaD and ipaH was previously described by Faruque et al. (2002). Invasion capacity was assessed by Hep-2 infection assays (Francis et al. 1991) and efficiency of infection was determined by visually scoring ethanol-fixed, Giemsa-stained cells after treatment with a balanced salt solution containing gentamicin (Mantis et al. 1996); this treatment exclusively kills extracellular bacteria and eliminates noninvasive bacteria. Chi-squared analyses were performed using Fisher's exact tests.

Gastroenteritis was found predominantly in children younger than 24-months of age with Shigella spp., representing the fourth major cause of diarrhea, preceded only by rotavirus, diarrheagenic $E$. coli and Salmonella sp. (Orlandi et al. 2006). Twenty-four Shigella spp. were isolated, of which $72 \%$ were S. flexneri, 
$12 \%$ S. boydii, $12 \%$ S. sonnei and $4 \%$ S. dysenteriae; the frequency of Shigella comparing with all enteropathogens was $5.1 \%$. Slide agglutination assays revealed the presence of $16 S$. flexneri type II and two type III strains, three $S$. sonnei, three $S$. boydii and one $S$. dysenteriae. However, the low frequency of $S$. dysenteriae may have been due to non-specific $S$. dysenteriae present in the culture media.

High levels of resistance to trimethoprim/sulfamethoxazole, ampicillin, amicacin, penicillin and cotrimoxazol were observed. Eighteen S. flexneri isolates displayed resistance to multiple antibiotics, as well as a low frequency of resistance to nalidixic acid and quinolones (ciprofloxacin and norfloxacin).

PCR-based detection of ipaBCD and ipaH genes showed the presence of ipaH in 17 of 18 S. flexneri isolates, and all isolates were positive for ipaBCD. Two of three $S$. sonnei and $S$. boydii isolates tested positive for $i p a H$ and ipaBCD virulence genes, while $S$. dysenteriae did not. We observed 19 ipaH+ and inv+, three ipaHand inv-, two ipaH+ and inv- and one ipaH-and inv+ strains by invasion phenotyping, and $20 \mathrm{ipaBCD}+$ and inv+, three ipaBCD- and inv- and one ipaBCD+ and invgenotypes. The $S$. flexneri collected from stool of nonenteric subjects was unable to invade HeLa cells.

An association of colitis with bloody diarrhea and fever was observed in 20 patients. Nineteen had ipaH+ $\left(\chi_{2 \mathrm{t}}^{2}\right.$ $5.38, \mathrm{p}=0.016)$ (Table) and among the five patients without colitis, two contained the ipaH gene. All 20 colitis patients were Shigella ipaBCD+ $\left(\chi_{2+}^{2} 8.55 \mathrm{p}=0.0043\right)$ (Table).

All 20 Shigella isolates from subjects associated with colitis were able to invade HeLa cells and five Shigella isolates from patients without colitis could not invade HeLa cells $\left(\chi_{2 \mathrm{t}}^{2} 19.14, \mathrm{p}=0.000018\right)$ (Table).

PCR detection of ipa virulence genes represents an excellent tool for diagnosis of shigellosis (Thiem et al. 2004). Our data revealed an association between colitis enteric and children with shigellosis.

\section{TABLE}

Analysis between colitis presented by infected children and ipa $H$, or ipaBCD or invasion phenotypes

\begin{tabular}{lcc}
\hline & Colitis $^{a}$ & Without colitis \\
\hline IpaH & 19 & 2 \\
Positive & 1 & 3 \\
Negative & $\chi_{2 \mathrm{t}}^{2}=5.38$ & $\mathrm{p}=0.016$ \\
& 20 & 2 \\
Ipa BCD & 0 & 3 \\
Positive & $\chi_{2 \mathrm{t}}^{2}=8.55$ & $\mathrm{p}=0.0043$ \\
Negative & 20 & 0 \\
Invasion & 0 & 5 \\
Positive & $\chi_{2 \mathrm{t}}^{2}=19.14$ & $\mathrm{p}=0.000018$ \\
Negative & & \\
&
\end{tabular}

$a$ : colitis characterized by diarrhea with fever and blood in the stools.
While $S$. flexneri and $S$. dysenteriae were found to be quite common in areas with inadequate sanitation, $S$. sonnei prevalence was related more too contaminated food and drink in developed countries (Lima et al. 1997, Faruque et al. 2002). According to the present study, incidence of shigellosis along the Porto Velho border is far worse than in other poorer areas of Brazil due to the presence of the uncommon $S$. boydii strain.

Many studies have previously described Shigellosis frequencies around 3-6\% (Leal et al. 1988, 1998, Lima et al. 2000, Medeiros et al. 2001). Orlandi et al (2001) also found a $6.1 \%$ frequency of $S$. flexneri in 130 children with diarrhea and the frequencies and predominance of $S$. flexneri were similar to those observed in different states of Brazil (Leal et al. 1988, 1998, Lima et al. 2000) as well as in other tropical countries (Navia et al. 1999).

In our study we have analyzed colitis related to different virulence factors, the presence of ipaH or ipaBCD genes and the ability to invade HeLa cells. Our data has shown that all these phenotypes are associated with colitis (Table), although the ability to invade HeLa cells was not strictly associated with the presence of ipa virulence genes.

The presence of multiple antibiotic resistant Shigella isolates, Shigella in children with nonenteric pathologies and identification of diarrhea without dysentery detaches the presence of Shigella within our region.

\section{REFERENCES}

Faruque SM, Khan R, Kamruzzaman M, Yamasaki S, Ahmad QS, Azim T, Nair GB, Takeda Y, Sack DA 2002. Isolation of Shigella dysenteriae type 1 and $S$. flexneri strains from surface waters in Bangladesh: comparative molecular analysis of environmental Shigella isolates versus clinical strains. Appl Environ Microbiol 68: 3908-3913.

Francis CL, Jerse AE, Kaper JB, Falkow S 1991. Characterization of interactions of enteropathogenic Escherichia coli 0127:H6 with mammalian cells in vitro. J Infect Dis 164: 693-703.

Leal NC, Cavalcanti TIR, Silva MJB, Reis EMF, Solaria CA, Hofer E 1988. Frequência de enterobactérias patogênicas em processos diarréicos infantis na cidade do Recife, Pernambuco, Brasil. Mem Inst Oswaldo Cruz 83: 475-479.

Leal NM, Cavalcanti TIR, Prazeres D, Hofer E 1998. Enteropatógenos detectados em crianças sadias em três comunidades de baixa renda, em Recife, Estado de Pernambuco, Brasil. Mem Inst Oswaldo Cruz 93: 153-159.

Lima AAM, Barboza MS, Soares AM, Schleupner MA, Newman RD, Sears CL, Nataro JP, Fedorko DP, Wuhib T, Schorling JB, Guerrant RL 2000. Persistent diarrhea signals a critical period of increased diarrhea burdens and nutritional shortfalls: a prospective cohort study among children in Northeastern Brazil. J Infect Dis 181: 1643-1651.

Lima AAM, Sidrim JJC, Lima NL, Titlow W, Evans ME, Greenberg RN 1997. Molecular epidemiology of multiply antiotic-resistant Shigella flexneri in Fortaleza, Brazil. J Clin Microbiol 35: 10611065 .

Mantis N, Prévost MC, Sansonetti P 1996. Analysis of epithelial cell stress response during infection by Shigella flexneri. Infect Immun 64: 2474-2482.

Mates A, Eyny D, Philo S 2000. Antimicrobial resistance trends in Shigella serougroups isolated in Israel, 1990-1995. Eur J Clin Microbiol Infect Dis 19: 108-111. 
Medeiros MI, da Silva S, Neme P, Capuano DM, Errera MC, Fernandes SA, do Valle GR, de Avila FA 2001. Etiology of acute diarrhea among children in Ribeirão Preto - SP, Brazil. Rev Inst Med Trop 43: 21-24.

Navia MM, Capitano L, Ruiz J, Vargas M, Urassa H, Schellemberg D, Gascon J, Vila J 1999. Typing and characterization of mechanisms of resistance of Shigella spp. isolated from feces of children under 5 years of age from Ifakara, Tanzania. J Clin Microbiol 37: 3113-3117.

Orlandi PP, Magalhães GF, Matos NB, Silva T, Penatti M, Nogueira PA, Pereira da Silva LH 2006. Etiology of diarrheal infections in children of Porto Velho (Rondônia, Western Amazon region, Brazil). Braz J Med Biol Res 39: 507-517.

Orlandi PP, Silva T, Magalhães GF, Alves F, Cunha RPA, Durlacher RR, Pereira da Silva LH 2001. Enteropathogens associated with diarrhealdiseaseininfantsof poorurbanareas ofPorto Velho, Rondônia: a preliminary study. Mem Inst Oswaldo Cruz 96: 621-625.

Thiem VD, Sethabutr O, Seidlein LV, Tung TV, Canh DG, Chien BT, Tho LH, Lee H, Houng HS, Hale TL, Clemens JD, Mason C, Trach DD 2004. Detection of Shigella by PCR assay targeting the $i p a H$ gene suggests increased prevalence of Shigellosis in Nha Trang, Vietnam. J Clin Microbiol 42: 2031-2035. 